\title{
Growing Up Okie: An Interview with Roxanne Dunbar-Ortiz
}

In Red Dirt: Growing Up Okie (New York 1997) Roxanne Dunbar-Ortiz uses the compelling personal history of her family to tell the larger story of a neglected group, poor rural white Americans. Animating the book is the paradoxical story of how this group, once a breeding ground of radicalism, has become a bulwark of the American right. Grandchildren of Wobblies and Okies can now be found supporting the Christian Coalition, the Republican Party and even white supremacist militias. Her book makes clear that right-wing populism derives much of its power from the souring of radical hopes and the repression of genuinely egalitarian political movements. In addition, Dunbar-Ortiz grapples with how white racial identity offers consolation to the "foot soldiers of empire." Her book commends itself to all those interested in radical politics, the history of rural peoples, and the formation of racial identities.

Roxanne Dunbar-Ortiz is Professor of Ethnic Studies and Women's Studies at California State University. Her books include Roots of Resistance: Land Tenure in New Mexico and The Great Sioux Nation. In this interview, conducted by Danny Postel for his radio program Free Associations, Dunbar-Ortiz talks about her radical roots in a world of Wobblies, Okies, and the Klan.

Postel: Roxanne, you say that your book Red Dirt: Growing Up Okie is really a life history, telling the story of your life and your family. You say it's a book "about growing up rural and poor in Oklahoma, a kind of historical study that would tell the story of a people and a place through one life, mine, and about our people who went to California." Your family is central to the narrative and to the picture that you paint. Your father grew up a sharecropper but his father was a member of the Industrial Workers of the World (IWW), the Wobblies. Now those are terms that might not even be familiar to a lot of people these days. Why don't you go ahead and give us a little bit of a sense of who the Wobblies were?

Dunbar-Ortiz: Well, it's no wonder that people don't know about it because it's not in the history textbooks. I'm a historian with a Ph.D. and the only way I know about it is from my being told the stories about my grandfather when I was growing up. Most of the people who formed the Industrial Workers of the World came out of the Socialist Party in 1905. They didn't set it up as splinter group but as a practical organizing device of one big union, everyone in the same union. The Socialist Party was a political party so they set the IWW up as a union but without division into crafts and trades because they saw that as pitting one set of workers against another. They wanted a living wage, the same wage 
structure for all workers, and a people's banking system with no interest. They wanted to end foreign wars. They were pacifists even though they were anarchists and were not completely free of violent tendencies. They very much opposed wars, and the state carrying on wars. They opposed the death penalty. They supported the equal rights of women before women had the right to vote and equality among the races.

Postel: You say early on in a chapter entitled "Red Diaper Baby?" you asked your father, "What did the Wobblies want?" and "No matter how many times he told me, I loved to hear his agenda of Wobbly dreams. Abolition of interests and profits, public ownership of everything, no military draft, no military, no police, the equality of women and all races. 'The O-B-U, One Big Union.' He would say and smile to himself, lost in memory."

Dunbar-Ortiz: Yes, and he would like to deny now anything to do with the Wobblies. There were 13,000 dues paying socialists in Oklahoma. It was the largest single grouping of socialists in the Socialists Party in America.

Postel: One doesn't normally associate Oklahoma as a hotbed of socialism.

Dunbar-Ortiz: And a real trade unionists state. The actual constitution of Oklahoma is extremely progressive and you would never know it now because when the repression came during World War I it was focused on Oklahoma. There were Wobbly leaders getting deported, Big Bill Haywood skipping bail and going to the Soviet Union. Of course, the Wobbly activity within the Socialist Party was all before the Russian Revolution, so it can't be said this was foreign manipulation or treason. These were real homegrown people who had links all over the world but generally they were the leaders of these linkages with other workers around the world.

Postel: These were "real Americans".

Dunbar-Ortiz: And these were the real Americans, the down-home Americans. So the leaders in the Socialist Party met in Chicago and formed the IWW. Bill Haywood is the best known, but there was also William Moyer and George Pettibone. Of course, Mother Jones and Emma Goldman were there. They went ahead and voted for Eugene Debs, who was there and supported it. Well very soon, within four years in 1907, those leaders were on trial in Boise City for capital crimes.

Postel: This was sort of the western version of the Haymarket tragedy.

Dunbar-Ortiz: Exactly. They were defended by Clarence Darrow, who got them off. My father was born during that trial and my grandfather named him after them: Moyer Haywood Pettibone Scarberry Dunbar. That's how my father got the name of all the Wobbly leaders on his birth certificate. My grandfather had joined the Socialist Party several years before that. Now his profile is 
interesting: my grandfather was a farmer. He had moved in from Missouri. He was already in the Socialist Party. Kansas, Missouri and Oklahoma were real centers of socialism. He moved his family to this little town where I grew up in central Oklahoma. So they settled this little town and they were really like the town fathers and mothers. No one was rich but they had land and they had farms and they farmed. Then my grandfather when he was thirty-five years old went back to Missouri and did his medical degree in veterinary medicine.

Postel: And they had a big family, he had ten children.

Dunbar-Ortiz: Eleven. Eventually eleven. He came back after three years of being gone. Meanwhile my grandmother was taking care of the farm and the older kids kept it going. He came back and was a highly respected veterinarian. He was school board president. The Wobblies took local power in almost every town in Oklahoma and throughout the whole western region of the United States. It's quite an extraordinary thing. They went for local power. The Socialist Party always ran people for larger offices, like Eugene Debs. He always got a larger share of the vote in Oklahoma then any other place, twenty to twenty-five per cent. It was really quite extraordinary because the IWW was also such a blatantly radical movement. It was radical in ways that were shameless. They would get accused of being traitors, the 1950s thing. The accusation of being unpatriotic came with their opposition to World War I. They weren't just pacifists. They called it a rich man's war and they were pretty much right. The war led to utter disasters after that, the Weimar Republic and then fascism. The Wobblies were horribly smashed. They were beaten up. The Ku Klux Klan was revived by the powers-that-be, although it had been moribund for years.

Postel: And this brings us directly into your family's story too because the $\mathrm{Ku}$ Klux Klan had a direct bearing on your family's politics and economic life.

Dunbar-Ortiz: Before the Klan, there were the Palmer Raids. The Justice Department raided every Socialist office and IWW office, wrecked their printing presses, arrested leaders and deported anyone who was foreign-born. In west Oklahoma, the main people who had socialistic tendencies were farmers. They were Catholic and foreign-born Czechs, Poles and Germans. The way they framed the attack on the Socialists and Wobblies in Oklahoma was that they were foreigners, that they were working with the Kaiser, especially the Germans, and that they were traitors who couldn't be trusted. So whole mobs would go out beat them up. There's a scene in John Steinbeck's East of Eden of that happening in California. So the Ku Klux Klan, being anti-Catholic to begin with, made Catholics and the foreign-born the main target of their attack. Except for work crews of migrant cotton pickers, blacks weren't really allowed to settle in western Oklahoma by the powers-that-be. They had to be out of town by after 
dark. The Indians were so repressed and in tiny little enclaves. So the Ku Klux Klan focused on attacking the Catholics and foreign-born. They infiltrated the Masons in Oklahoma and they took over the Baptist church. Through these institutions in other places like Texas and Arkansas, the Klan took over the governorship. They actually came to power. The Klan also did night-raiding, they beat my grandfather in front of my grandmother and the children until he was almost dead. He had to have a steel plate put in his head. My dad is convinced this killed my grandfather, although he lived ten more years. My grandfather was kicked by a horse he was doctoring and died soon after but if it had not been for that previous injury, he wouldn't have died as young as he did. He wasn't all that old.

Postel: So the Klan in a sense killed your grandfather.

Dunbar-Ortiz: That's my dad's feeling. At least metaphorically the Klan drove them out. My grandmother was terrified. Here you have all these little kids to take care of and she wanted to get out of there. So my grandfather sold everything really cheap, real fast and just packed up what they could carry and they all moved down to the Rio Grande Valley in Texas.

Postel: Where you were born.

Dunbar-Ortiz: Well, I was born in San Antonio. But they went back and forth. My father was, and remains, attached to that place in Oklahoma. He's never wandered very far from it. It was his home, his town. I think he felt too that he had to vindicate his father as well. So he ran away from home at sixteen, went back up to Oklahoma where there were still some relatives. He worked as a regular line-rider, which people usually call cowboys. They string the barbed wire on the big ranches, very hard proletarian work. Indians, blacks, and poor whites and Mexicans did this work. And he became extremely good at rodeo-ing and everything else. He was a cowboy and quit school in the ninth grade. But he stayed there, he tried to stay as close as he could to Piedmont and was very attached to the place. He met my mother when he was working for her sister, who was married to a farmer. He was working for them as a farm labourer. My mother was fifteen and my father was seventeen. The next year they got married. That was in 1927. Things didn't look all that bad in 1927. They were young and poor. They were both working as farm labour. Then of course the Depression hit. They had their first child and another one came soon after. They lived in sod-huts and caves. They were homeless sometimes and lived in cars, mainly did cottonpicking. Then my dad started getting some sharecropping work. So they were moving around but it was all in this one county, where my brother and sister went to a different school two or three times a year. Little country schools. Me and my other brother weren't born for another eight years later, they had a kind of second 
family in the late thirties, so I didn't have to experience the worst of it but it was pretty much institutionalized by the time I came along. My dad was a sharecropper or rented. During that period they worked for the WPA. They almost starved. My father's big thing, he wanted to stay on the land, have land, to raise his own food, to have his own hogs and a milk cow, to feed his family because the worst thing you can think of is not to be able to at least eat. So he just refused to be uprooted from the land or to go to California or to move to the city. Part of it was also, he wanted to be there in Piedmont and to say I am here and I have the right to be here. The Dunbars have a right to be here.

To read the complete interview, please go to

http://www.yorku.ca/research/lefthist

To listen to the complete interview, go to

http://www.freespeech.org/associates 